\title{
Immunocontrolling Graphene Oxide Catalytic Nanogold Reaction and Its Application to SERS Quantitative Analysis
}

\author{
Aihui Liang, ${ }^{\dagger}$ Chongning Li, ${ }^{\dagger}$ Xiaoliang Wang, ${ }^{\dagger}$ Yanghe Luo, ${ }^{\dagger, \dagger}$ Guiqing Wen, ${ }^{* \dagger}$ and Zhiliang Jiang $*^{*}{ }^{\dagger}$
}

${ }^{\dagger}$ Key Laboratory of Ecology of Rare and Endangered Species and Environmental Protection (Guangxi Normal University), Ministry of Education, Guangxi Key Laboratory of Environmental Pollution Control Theory and Technology, 541004 Guilin, China

${ }^{\ddagger}$ School of Food and Bioengineering, Hezhou University, 542899 Hezhou, China

Supporting Information

ABSTRACT: The gold nanoreaction between $\mathrm{HAuCl}_{4}$ and $\mathrm{H}_{2} \mathrm{O}_{2}$ is very slow at $50{ }^{\circ} \mathrm{C}$, and the nanoenzyme of graphene oxide (GO) greatly catalyzes the nanoreaction to form gold nanoparticles (AuNPs) with high SERS activity in the presence of Vitoria blue 4R (VB4r) molecular probes, strong resonance Rayleigh scattering (RRS), and surface plasmon resonance (SPR) absorption effect. With the increase of GO, the SERS, RRS, and SPR absorptions were enhanced linearly due to the formation of more AuNPs. The rabit antibody of human chorionic gonadotropin (RHCG) strongly adsorbed on the GO surface to inhibit its catalysis. Upon addition of human chorionic gonadotropin (HCG), the RHCG is separated from the GO surface due to the formation of HCG-RHCG specific immunocomplexes, which led to the recovery of GO catalysis. Using the new strategy of immunocontrolling GO catalysis, three types of resonance methods including SERS, RRS, and surface plasmon resonance (SPR) absorption have been developed for detection of HCG.

\section{INTRODUCTION}

Nanoparticles such as gold and graphene oxide not only are of enzyme property but also have high SERS activity. Since the $\mathrm{Fe}_{3} \mathrm{O}_{4}$ nanoenzyme was reported, ${ }^{1}$ research interest has risen rapidly, and it has been involved widely in different fields such as materials, physics, chemistry, biology, medicine, and environmental sciences. Compared with the natural bioenzyme, nanoenzymes have high stability and high catalytic activity, are cheap, and have other advantages over bioenzymes, especially to avoid the characteristics of bioenzymes of instability and variability. This unique property enhanced the application prospect of nanoenzymes in process catalysis and enzyme kinetics. Thus, these nanoparticles with catalytic activity have important significance in analytical chemistry. At present, the analytical application is mainly involved in the detection of heavy metal ions and biological molecules, ${ }^{2-8}$ based on nanoenzyme catalytic colored reactions. Seok et al. ${ }^{2}$ detected mercury ions, which based on the principle of ssDNA magnetic nanoparticles can inhibit the $\mathrm{H}_{2} \mathrm{O}_{2}$ oxidation of phthalate to amine with no color, and 5-75 $\mu \mathrm{moL} / \mathrm{L}$ of $\mathrm{Hg}$ (II) caused the color deepening. Lien et al. ${ }^{3}$ used fluorescence enhancement to detect thrombin for $\mathrm{H}_{2} \mathrm{O}_{2}$ oxidization of Amplex reagent by thrombin transforming protein-mediated Bi-AuNPs, and Jiang et al. ${ }^{4}$ reported a simple nanogold catalytic spectrophotometric method for 2-10 nmoL/L of glucose. Surface-enhanced Raman scattering (SERS) is due to some molecules adsorbed on a rough surface of the nanoparticles that caused the Raman
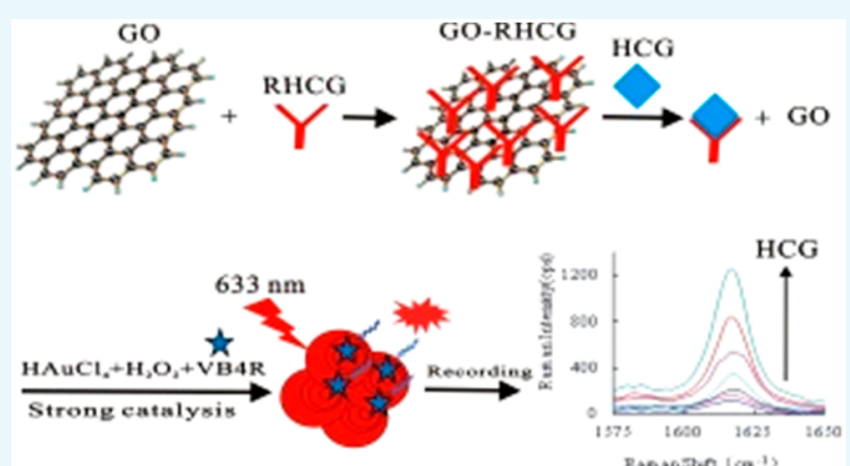

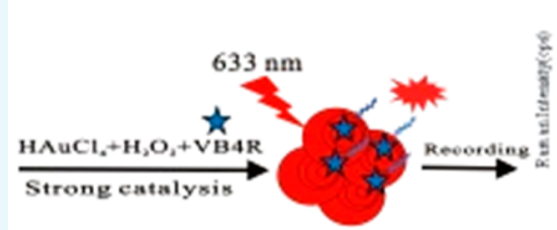

scattering signal-enhanced phenomenon..$^{9-12}$ It not only sensitively detects the concentration of molecules adsorbed on the nanosurface but also gives rich information on the molecular structure and has been widely used in materials, chemicals, polymer materials, biological, environmental protection, and other fields. ${ }^{13,14}$ According to the use of molecular probe markers, SERS can be divided into SERS marking technology and free-label SERS technology. SERS free-label technology is directly detected by the Raman signal itself or use of dye molecules to probe the Raman signal, according to the Raman fingerprints of the material to be quantitatively or qualitatively analyzed, with some advantages such as simple, fast, and direct use of the sample Raman characteristic signal without additional marking processing of the sample, which avoids the destruction of the sample, and these merits attract much attention. ${ }^{15,16}$ In addition, we have known that stable and highly SERS-active nanosol substrates are very important to SERS quantitative analysis. Although some gold nanosol substrates prepared by citrate and $\mathrm{NaBH}_{4}$ were used, the stable and highly SERS active nanosol substrate and nanoreaction with SERS activity will be explored still in SERS quantitative analysis, by means of green nanocatalytic synthesis.

Received: September 8, 2017

Accepted: October 6, 2017

Published: October 27, 2017 
a
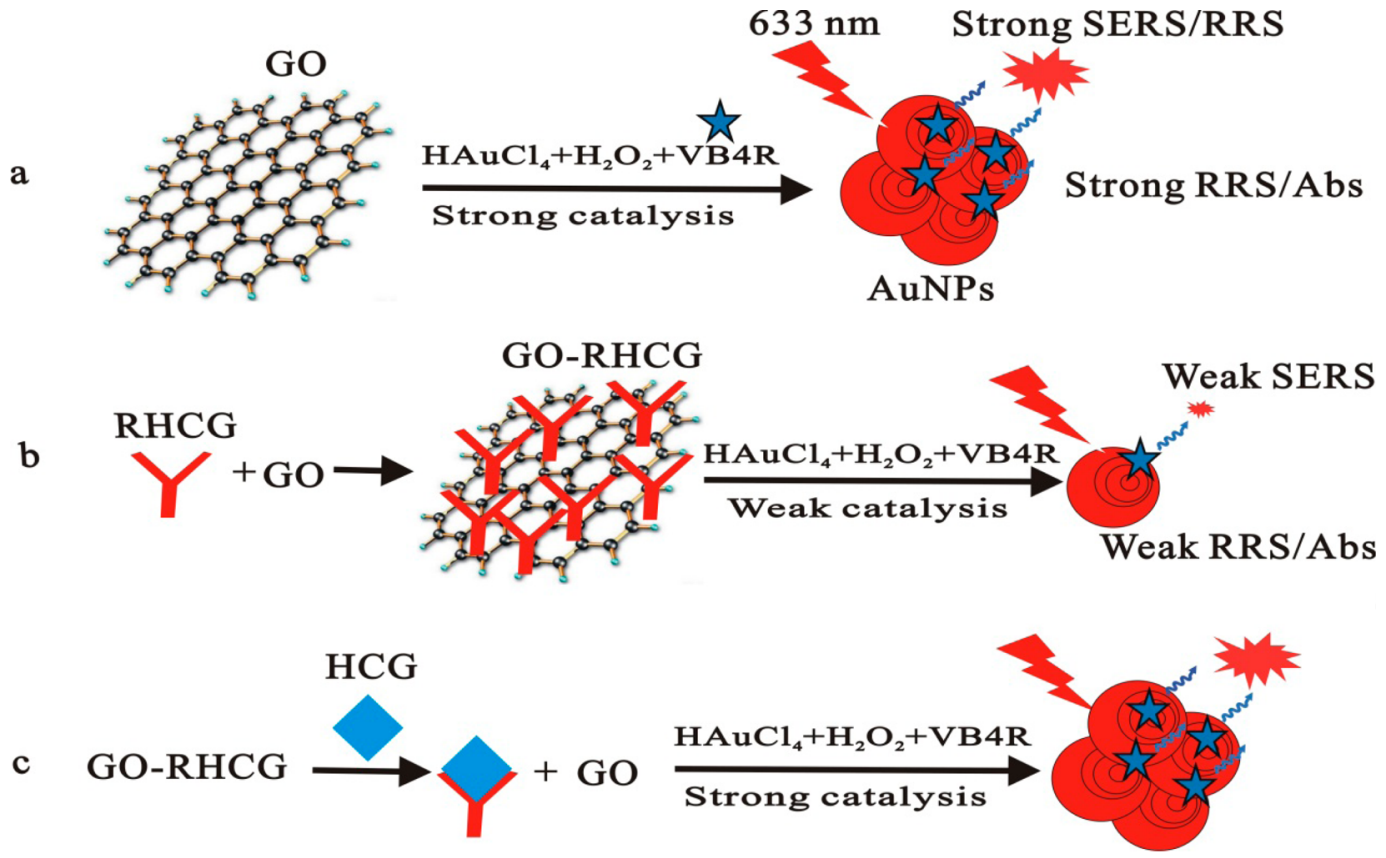

Figure 1. Scheme of the immunecontrolling GO catalytic activity-SERS detection of HCG. (a) GO catalyzed the formed AuNPs with strong SERS. (b) RHCG inhabited the nanocatalytic reaction with weak SERS. (c) HCG recovered the nanocatalysis to form AuNPs with strong SERS.

Metal-free catalysts are newly emerging green catalytic materials that have attracted much attention in recent years for their advantanges of high efficiency, environmental friendliness, and economy in many industrial catalytic processes. ${ }^{17,18}$ An important type of inorganic metal-free catalyst is nanocarbon materials that have demonstrated superior catalytic performance to traditional metal catalysts in many fields. ${ }^{19,20}$ Metal-free carbon-based catalysis has become one of the most promising research directions in nanomaterials and catalysis. The carbon material itself is used as the catalyst, and no metal is loaded or added; therefore, the active sites for the reaction are the defective structure or functional groups on the carbon surface. Graphene oxide (GO) is a kind of new carbon material with excellent performance such as good catalysis, high specific surface area, and abundant surface hydroxyl groups. ${ }^{21-26}$ In recent years, it has become a hot spot due to its unique physical, chemical, and biological characteristics. $^{27-29} \mathrm{He}$ et al. $^{27}$ reported that GO prepared by the Hummers method could catalyze the hydrolysis of soybean isoflavones. In the nanoanalysis, ${ }^{30-38}$ Wang et al. established a resonance Rayleigh scattering (RRS) method to detect HSA, using GO as a probe. ${ }^{30}$ The SERS effect of GO was studied by Hao et al. ${ }^{31}$ The SERS properties of GO/Au/Ag composites were better than those of pure gold and silver nanoparticles. Banchelli's research group found that $\mathrm{GO}-\mathrm{Ag}$ composite nanoparticles were more effective than silver nanomaterials when used as a substrate in SERS analysis. ${ }^{32}$ Wang et al. ${ }^{33}$ used $\mathrm{Cu}^{2+}$-ion-modified graphene oxide nanoparticles as a heterogeneous catalyst, mimicking functions of horseradish peroxidase for the chemiluminescence detection of $\mathrm{H}_{2} \mathrm{O}_{2}$ and glucose. The dispersed $\mathrm{Co}_{3} \mathrm{O}_{4}$ nanoparticle-decorated crumpled graphene microsphere (CGM) possessed intrinsic peroxidase-like activity and could catalytically oxidize $3,3^{\prime}, 5,5^{\prime}$-tetramethylbenzidine by $\mathrm{H}_{2} \mathrm{O}_{2}$ to produce a typical blue product and can be used to detect $30-140 \mu \mathrm{M}$ ascorbic acid colorimetrically. ${ }^{34}$ An amperometric sensor was established for the detection of 0.1-43 $\mu \mathrm{M}$ indole-3-acetic acid, based on the hemin/reduced graphene oxide (hemin/rGO) composite with peroxidase-like activity. ${ }^{35}$ Rapid detection of sarcosine is a key requirement for both diagnosis and treatment of disease. A simple and sensitive colorimetric nanocomposite platform was reported for rapid detection of $0.73 \mu \mathrm{M}$ sarcosine, ${ }^{36}$ based on the GO catalysis of the colored reaction of 1, 2-naphthoquinone-4-sulfonic acid sodium salt (NQS) that functionalized the GO nanocomposite through $\pi-\pi$ stacking. At present, there are no reports about GO catalytic nanoparticle reaction with SERS activity and its application in nanoanalysis.

HCG is a glycoprotein secreted by the placenta trophoblast cells, and it is an important medical diagnostic marker of pregnancy. It also is one of the important markers of clinical diseases, and its content is closely related to some diseases, such as gestational trophoblastic disease, germ cell tumors, and Down syndrome. ${ }^{39}$ In addition, the quantitative detection of HCG is of great significance to the analysis of clinical medicine and the abuse of stimulants. Immunoassay is a sensitive and selective analytical technology and was greatly paid attention by analysts. ${ }^{40-43}$ The detection methods are mainly immunoassays such as electrochemical, electrochemiluminescence, chemiluminescent, chemiluminescence resonance energy, fluorescence, resonance Rayleigh scattering, enzyme, and radioassay. ${ }^{44-46}$ Among them, the electrochemical immunoassay method has high sensitivity, but the operation is complex; the cost of fluorescence immunoassay is low, but there is a fluorescence quenching effect. Radioimmunoassay is widely used, but there are radiation hazards. Immunogold assay was the most mature and most widely used method for rapid detection of HCG, but this method can only detect whether or not HCG is present, and it is difficult to analyze the content. However, the application of SERS monitoring the GO catalytic oxidationreduction nanoparticle reaction, the regulation of the GO catalytic activity by immune reaction, and its application in nanoanalysis have not been reported. In this paper, a new SERS quantitative analysis method was developed for HCG, 

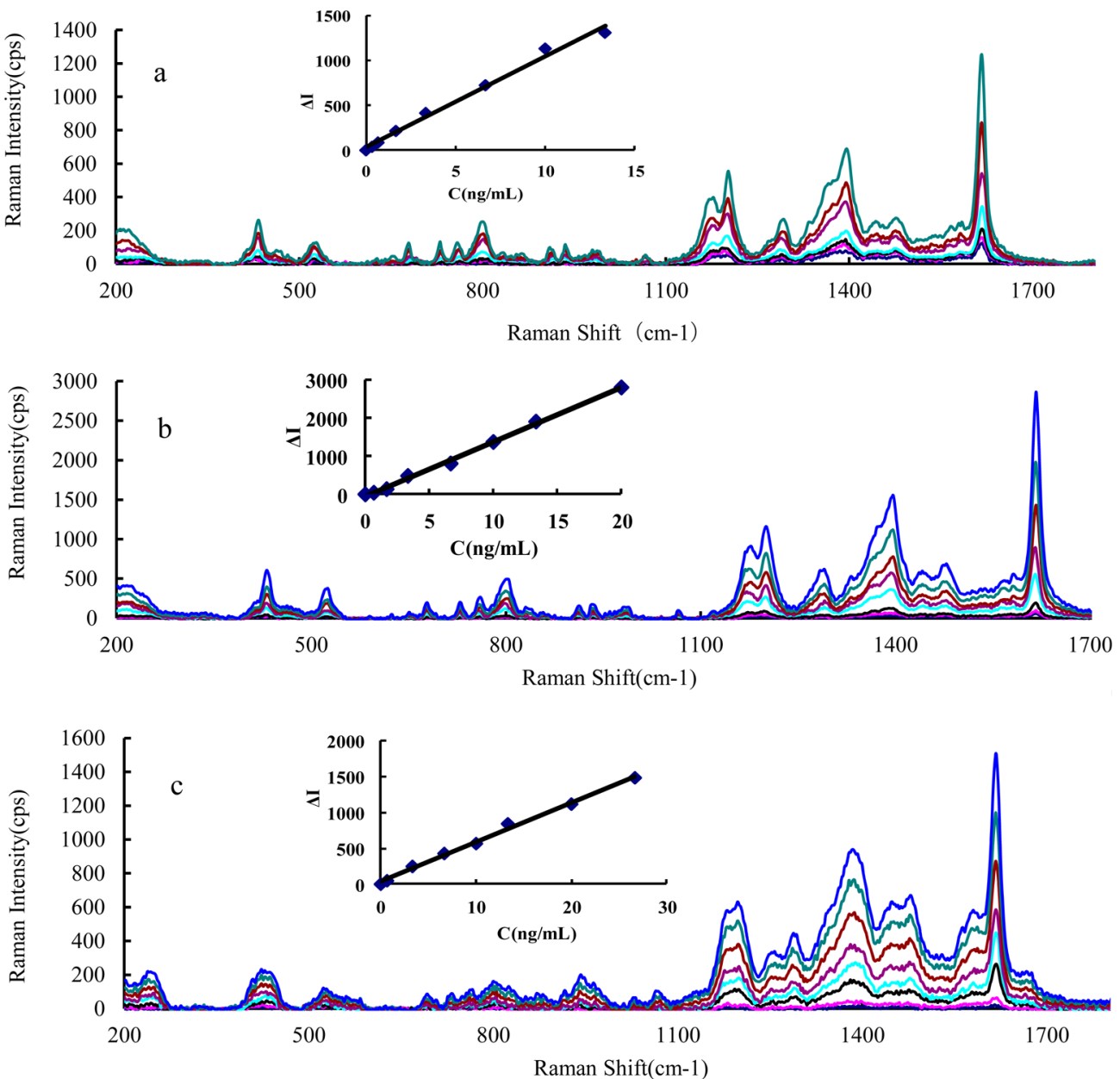

Figure 2. SERS spectra of the immunecontrolling GO catalytic system. (a) From low to high, the curves of the $13.33 \mathrm{ng} / \mathrm{mL} \mathrm{RHCG}+50 \mathrm{ng} / \mathrm{mL}$ $\mathrm{GO}+0.15 \mathrm{mmoL} / \mathrm{L} \mathrm{HCl}+2.5 \mathrm{mmoL} / \mathrm{L} \mathrm{H}_{2} \mathrm{O}_{2}+6.3 \mu \mathrm{moL} / \mathrm{L} \mathrm{HAuCl}_{4}+0.25 \mu \mathrm{moL} / \mathrm{L} \mathrm{VB} 4 \mathrm{r}$ system are $0,0.33,0.67,1.67,3.33,6.67,10$, and 13.33 $\mathrm{ng} / \mathrm{mL}$ HCG, respectively. (b) From low to high, the curves of the $13.33 \mathrm{ng} / \mathrm{mL} \mathrm{RHCG}+50 \mathrm{ng} / \mathrm{mL} \mathrm{GO}+0.167 \mathrm{mmoL} / \mathrm{L} \mathrm{HCl}+0.34 \mathrm{mmoL} / \mathrm{L}$ $\mathrm{TCA}+5.6 \mu \mathrm{moL} / \mathrm{L} \mathrm{HAuCl}{ }_{4}+0.25 \mu \mathrm{moL} / \mathrm{L}$ VB4r system are $0,0.67,1.67,3.33,6.67,10,13.3$, and $20 \mathrm{ng} / \mathrm{mL} \mathrm{HCG}$, respectively. (c) From low to high, the curves of the $20 \mathrm{ng} / \mathrm{mL}$ RHCG $+100 \mathrm{ng} / \mathrm{mL} \mathrm{GO}+0.5 \mathrm{mmoL} / \mathrm{LHCl}+50 \mathrm{mmoL} / \mathrm{L} \mathrm{GS}+5.6 \mu \mathrm{moL} / \mathrm{L} \mathrm{HAuCl}{ }_{4}+0.33 \mu \mathrm{moL} / \mathrm{L} \mathrm{VB} 4 \mathrm{r}$ system are $0,0.33,1,2,4,6,10$, and $13.33 \mathrm{ng} / \mathrm{mL} \mathrm{HCG}$, respectively.

based on the immune regulation of GO nanoenzyme activity of the gold nanoparticle reaction.

\section{RESULTS AND DISCUSSION}

Analysis Principle. Nanocatalytic reaction is an important route for analytical signal amplification and sensitivity improvement. The new nanoparticle catalytic reaction of $\mathrm{H}_{2} \mathrm{O}_{2}-$ $\mathrm{HAuCl}_{4}$ nanoparticle was investigated and used in the resonance scattering spectral analysis. The potential difference of $+0.307 \mathrm{~V}$ indicates the reaction could take place. In fact, the reaction is very slow in the absence of nanocatalyst. Therefore, the uncatalytic reaction system exhibits weak SERS signal due to low concentration of AuNP as substrate, in the presence of VB4r molecular probes. We have known that GO containing abundant surface $\pi$ electrons, the $\mathrm{AuCl}_{4}{ }^{-}$and $\mathrm{H}_{2} \mathrm{O}_{2}$, can be adsorbed on the GO surface, and the electron transfer of the AuNP reaction was enhanced greatly by means of the $\pi$ electrons. The produced small AuNPs could also act as nanocatalysts to speed the AuNP reaction. More AuNPs formed in the nanocatalytic system, and the SERS signal increased linearly with GO concentration. According to SERS theory, the SERS intensity $\left(I_{\text {SERS }}\right)$ is related to incident laser intensity $\left(I_{\text {in }}\right)$, molecular probe concentration $\left(C_{M}\right)$, and the enhancement factor $\left(E_{\mathrm{f}}\right)$ of substrate physical properties such as size and shape of nanoparticles and the degree of aggregation, etc. ${ }^{47-49}$ The difficulty in obtaining highly stable and reproducible SERS signals renders SERS a qualitative or semiquantitative detection technique. Although some methods such as internal standard have been used to correct SERS intensity variations induced by the variations in the physical properties of SERS substrate, the process is complicated, and the internal standard is uneasy to obtain. Using highly stable and reproducible nanosol as SERS substrate, simple and accurate SERS quantitative analysis methods could be developed, and the SERS signals depend on not only the $C_{\mathrm{M}}$ but also the nanosol concentration $\left(C_{N}\right)$; that is, $I_{\mathrm{SERS}}=K_{1} \times I_{\text {in }}$ $\times E_{\mathrm{f}} \times C_{\mathrm{M}}=K_{2} \times I_{\text {in }} \times C_{\mathrm{A}} \times C_{\mathrm{N}}=K_{3} \times C_{\mathrm{N}}$. When the experimental conditions hold constant, the $K$ is a constant; the $I_{\mathrm{SERS}}$ is linear to $C_{\mathrm{N}}$; and the nanocatalyst GO concentration $\left(C_{\mathrm{GO}}\right)$ is linear to $C_{\mathrm{N}}$, according to catalytic kinetics. Thus, the $I_{\mathrm{SERS}}$ is linear to $C_{\mathrm{GO}}$ that could be detected by SERS technique, as in Figure 1a. The RHCG has high affinity and specificity for antigen, and it can be easily adsorbed to the GO surfaces through electrostatic attraction that leads to weakening of GO catalysis (Figure $1 \mathrm{~b}$ ). When the HCG is present in solution, the RHCG selectively recognizes and tightly binds to HCG to form 

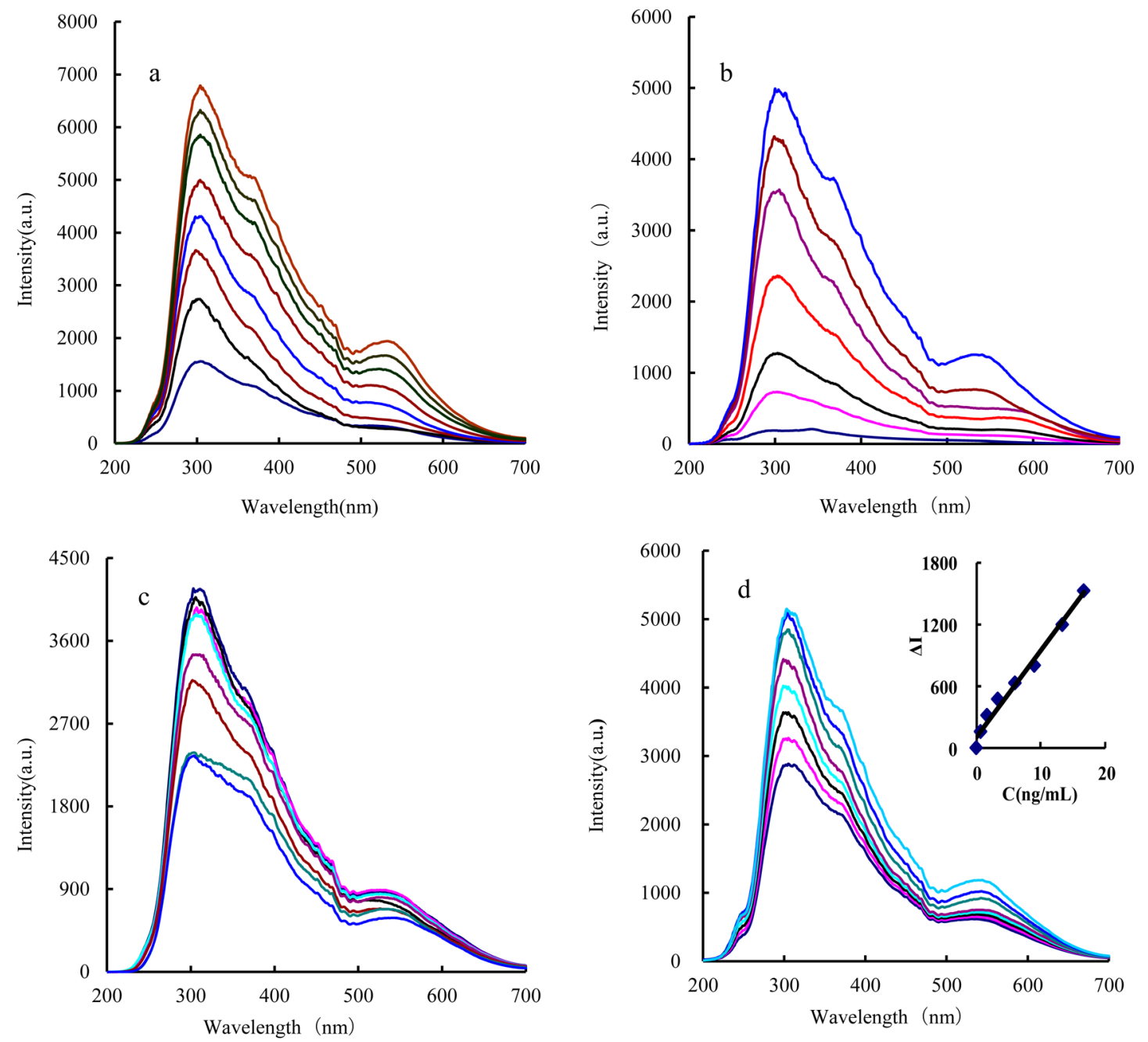

Figure 3. RRS spectra of the GO and AuNP nanocatalytic system. (a) From low to high, the curves of the $0.33 \mathrm{mmoL} / \mathrm{L} \mathrm{HCl}+2.8 \mu \mathrm{moL} / \mathrm{L}$ $\mathrm{HAuCl}_{4}+2.5 \mathrm{mmoL} / \mathrm{L} \mathrm{H}_{2} \mathrm{O}_{2}$ system are 0, 38.7, 96.7, 290, 580, 967, 1547, and $2320 \mathrm{ng} / \mathrm{mL}$ AuNP, respectively. (b) From low to high, the curves of the $0.15 \mathrm{mmoL} / \mathrm{L} \mathrm{HCl}+2.5 \mathrm{mmoL} / \mathrm{L} \mathrm{H}_{2} \mathrm{O}_{2}+6.3 \mu \mathrm{moL} / \mathrm{L} \mathrm{HAuCl}_{4}$ system are, $0,5,12.5,25,37.5,50$, and $75 \mathrm{ng} / \mathrm{mL} \mathrm{GO}$, respectively. (c) From high to low, the curves of the $50 \mathrm{ng} / \mathrm{mL} \mathrm{GO}+0.15 \mathrm{mmoL} / \mathrm{L} \mathrm{HCl}+2.5 \mathrm{mmoL} / \mathrm{L} \mathrm{H}_{2} \mathrm{O}_{2}+6.3 \mu \mathrm{moL} / \mathrm{L} \mathrm{HAuCl}_{4}$ system are $0,0.67,1.67,3.33,6.67$, 13.3, 20.0, and $26.67 \mathrm{ng} / \mathrm{mL}$ RHCG, respectively. (d) From low to high, the curves of the $35 \mathrm{nmoL} / \mathrm{L} \mathrm{RHCG}+50 \mathrm{ng} / \mathrm{mL} \mathrm{GO}+0.15 \mathrm{mmoL} / \mathrm{LHCl}$ $+2.5 \mathrm{mmoL} / \mathrm{L} \mathrm{H}_{2} \mathrm{O}_{2}+6.3 \mu \mathrm{moL} / \mathrm{L} \mathrm{HAuCl}_{4}$ system are $0,0.67,1.67,3.33,6,9,13.3$, and $16.67 \mathrm{ng} / \mathrm{mL} \mathrm{HCG}$, respectively.

immunocomplexes that escape from the GO surface and the GO catalytic activity recovery, and the SERS signal enhanced linearly due to the formation of more active AuNPs as substrate (Figure 1c). Thus, a new SERS method was developed for the determination of trace HCG, with high sensitivity and selectivity.

SERS Spectra. For the immuno-controlling system of $\mathrm{HAuCl}_{4}-\mathrm{H}_{2} \mathrm{O}_{2}$, the VB4r was used as a SERS probe; the main SERS peaks showed at $435 \mathrm{~cm}^{-1}, 803 \mathrm{~cm}^{-1}, 1197 \mathrm{~cm}^{-1}, 1203$ $\mathrm{cm}^{-1}, 1398 \mathrm{~cm}^{-1}$, and $1615 \mathrm{~cm}^{-1}$; the assignment of those SERS peaks was examined (Table S1); and the intensity increased linearly at $1615 \mathrm{~cm}^{-1}$ with the increase of HCG concentration (Figure 2a). For the immunocontrolling system of $\mathrm{HAuCl}_{4}-\mathrm{TCA}$ and $\mathrm{HAuCl}_{4}-\mathrm{GS}$, the SERS peaks showed at $434 \mathrm{~cm}^{-1}, 804 \mathrm{~cm}^{-1}, 1201 \mathrm{~cm}^{-1}, 1292 \mathrm{~cm}^{-1}, 1388 \mathrm{~cm}^{-1}$, and $1618 \mathrm{~cm}^{-1}$, and the SERS intensity increased linearly at 1613 $\mathrm{cm}^{-1}$ with the increase of HCG concentration (Figure $2 \mathrm{~b}, 2 \mathrm{c}$ ). In the three analytical systems, the $\mathrm{HAuCl}_{4}-\mathrm{H}_{2} \mathrm{O}_{2}$ system is the most sensitive and most stable and was chosen for SERS detection of HCG. The SERS spectra of $\mathrm{H}_{2} \mathrm{O}_{2}-\mathrm{HAuCl}_{4}-\mathrm{GO}$ nanocatalytic system were recorded (Figure S1A). The SERS intensity at $1617 \mathrm{~cm}^{-1}$ increased linearly with the increase of GO nanocatalyst concentration. Similarly, small AuNPs also exhibited strong catalysis of the $\mathrm{HAuCl}_{4}-\mathrm{H}_{2} \mathrm{O}_{2}$ reaction from the SERS spectra (FigureS1B). The SERS spectra of the RHCG-GO- $\mathrm{H}_{2} \mathrm{O}_{2}-\mathrm{HAuCl}_{4}$ system showed that the SERS intensity decreased linearly with the increase of RHCG concentration (Figure S1C), and RHCG has strong inhibition on the catalysis.

RRS Spectra. RRS is a sensitive spectral technique to determine trace metal and organic compounds such as protein and DNA, and it is also a good and sensitive tool to investigate nanoparticle reaction ${ }^{30,50-52}$ and was selected to study the AuNP nanreaction. The as-prepared AuNPs exhibited strong catalysis on the $\mathrm{HAuCl}_{4}-\mathrm{H}_{2} \mathrm{O}_{2}$ reaction that indicated that formed small AuNPs in the reaction process also have catalysis, in which there are two RRS peaks at 300 and $540 \mathrm{~nm}$ (Figure $3 a)$. The RRS spectra of GO- $\mathrm{HAuCl}_{4}-\mathrm{H}_{2} \mathrm{O}_{2}$, RHCG-GO$\mathrm{HAuCl}_{4}-\mathrm{H}_{2} \mathrm{O}_{2}$, and $\mathrm{RHCG}-\mathrm{HCG}-\mathrm{GO}-\mathrm{HAuCl}_{4}-\mathrm{H}_{2} \mathrm{O}_{2}$ nanocatalytic systems were recorded. All systems exhibited two RRS peaks at 300 and $540 \mathrm{~nm}$ (Figure 3c-3d), and GO, RHCG, and HCG have catalysis, inhabition, and recovery 

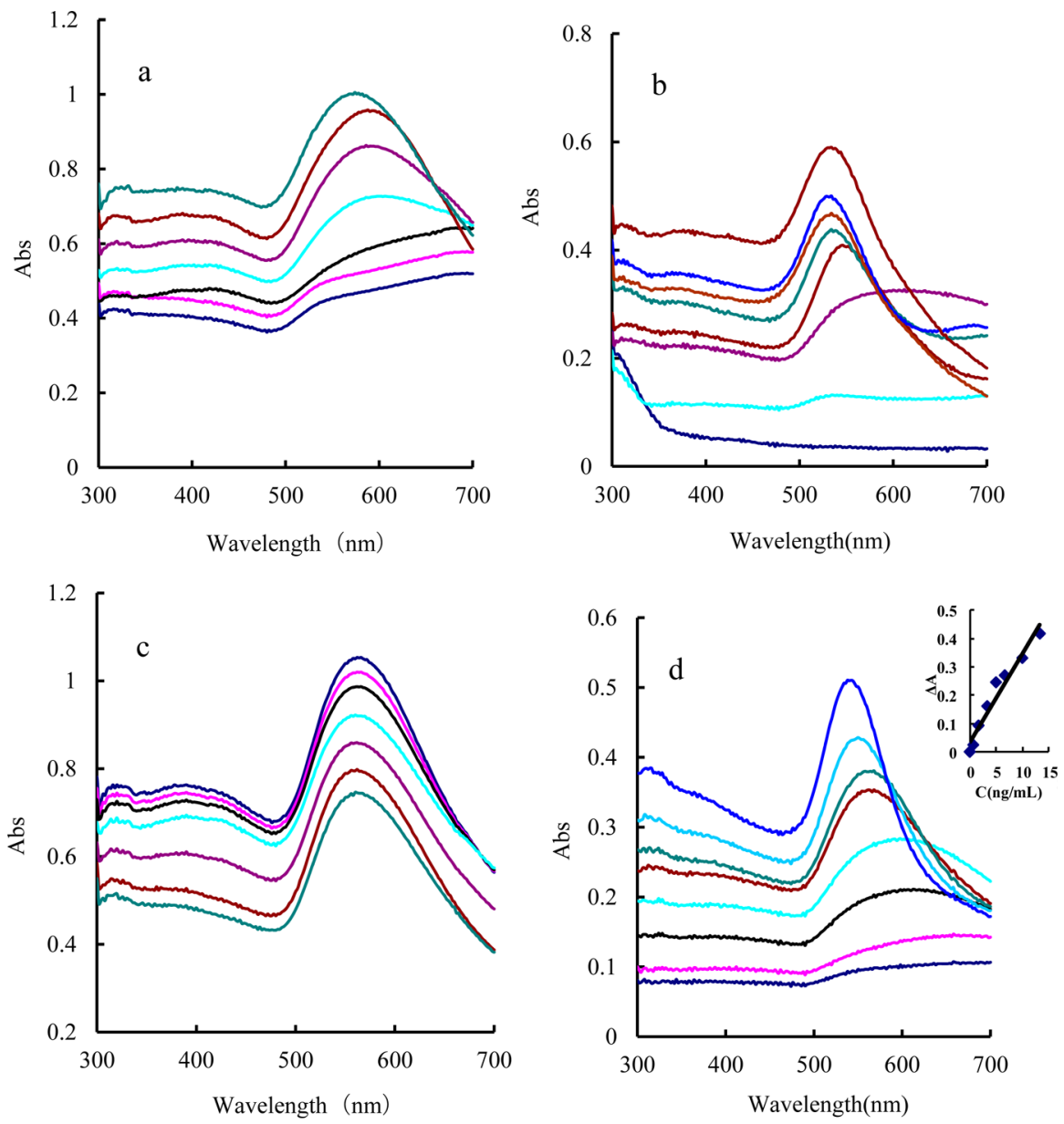

Figure 4. UV spectra of the GO and AuNP nanocatalytic system. (a) From low to high, the curves of the $0.15 \mathrm{mmoL} / \mathrm{L} \mathrm{HCl}+2.5 \mathrm{mmoL} / \mathrm{L} \mathrm{H} \mathrm{O}_{2}+$ $6.3 \mu \mathrm{moL} / \mathrm{L} \mathrm{HAuCl}_{4}$ system are $0,5,12.5,25,37.5,50$, and $75 \mathrm{ng} / \mathrm{mL} \mathrm{GO}$, respectively. (b) From low to high, the curves of the $0.33 \mathrm{mmoL} / \mathrm{L} \mathrm{HCl}$ $+2.8 \mu \mathrm{moL} / \mathrm{L} \mathrm{HAuCl}_{4}+2.5 \mathrm{mmoL} / \mathrm{L} \mathrm{H}_{2} \mathrm{O}_{2}$ system are 0, 96.67, 193.33, 386.67, 733.3, 1546, 2320, and 2706.6 ng/mL AuNP, respectively. (c) From high to low, the curves of the $50 \mathrm{ng} / \mathrm{mL} \mathrm{GO}+0.15 \mathrm{mmoL} / \mathrm{L} \mathrm{HCl}+2.5 \mathrm{mmoL} / \mathrm{L} \mathrm{H}_{2} \mathrm{O}_{2}+6.3 \mu \mathrm{moL} / \mathrm{L} \mathrm{HAuCl} \mathrm{H}_{4}$ system are $0,0.67,1.67,6.67$, 13.3, 20.0, and $26.67 \mathrm{ng} / \mathrm{mL}$ RHCG, respectively. (d) From low to high, the curves of the $35 \mathrm{nmoL} / \mathrm{L} \mathrm{RHCG}+50 \mathrm{ng} / \mathrm{mL} \mathrm{GO}+0.15 \mathrm{mmoL} / \mathrm{LHCl}$ $+2.5 \mathrm{mmoL} / \mathrm{L} \mathrm{H}_{2} \mathrm{O}_{2}+6.3 \mu \mathrm{moL} / \mathrm{L} \mathrm{HAuCl}_{4}$ system are $0,0.67,1.67,3.33,5,6.67,10$, and $13.3 \mathrm{ng} / \mathrm{mL} \mathrm{HCG}$, respectively.

Table 1. Comparison of the Nanocatalysis and the RHCG Inhibition

\begin{tabular}{lllll}
\multicolumn{1}{c}{ system } & method & \multicolumn{1}{c}{ linear range } & \multicolumn{1}{c}{ linear equation } & coefficient \\
$\mathrm{GO}-\mathrm{H}_{2} \mathrm{O}_{2}-\mathrm{HAuCl}{ }_{4}-\mathrm{VB} 4 \mathrm{r}$ & $\mathrm{SERS}$ & $5-50 \mathrm{ng} / \mathrm{mL} \mathrm{GO}$ & $\Delta I_{1615 \mathrm{~cm}-1}=68 \mathrm{C}+57$ & 0.9921 \\
& $\mathrm{RRS}$ & $5-75 \mathrm{ng} / \mathrm{mL} \mathrm{GO}$ & $\Delta I_{370 \mathrm{~nm}}=48 \mathrm{C}+120$ & 0.9911 \\
& $\mathrm{UV}$ & $5-75 \mathrm{ng} / \mathrm{mL} \mathrm{GO}$ & $\Delta A_{570 \mathrm{~nm}}=0.0077 \mathrm{C}+0.031$ & 0.9442 \\
$\mathrm{AuNP}-\mathrm{H}_{2} \mathrm{O}_{2}-\mathrm{HAuCl}_{4}-\mathrm{VB} 4 \mathrm{r}$ & $\mathrm{SERS}$ & $2-1000 \mathrm{nmoL} / \mathrm{L} \mathrm{Au}$ & $\Delta I_{1615 \mathrm{~cm}-1}=24.5 \mathrm{C}+107$ & 0.9766 \\
& $\mathrm{RRS}$ & $3-2000 \mathrm{nmoL} / \mathrm{L} \mathrm{Au}$ & $\Delta I_{370 \mathrm{~nm}}=2.014 \mathrm{C}+385$ & 0.9751 \\
& $\mathrm{UV}$ & $5-1000 \mathrm{nmoL} / \mathrm{L} \mathrm{Au}$ & $\Delta A_{530 \mathrm{~nm}}=0.0006 \mathrm{C}+0.0644$ & 0.8794 \\
$\mathrm{RHCG}-\mathrm{GO}-\mathrm{H}_{2} \mathrm{O}_{2}-\mathrm{HAuCl}_{4}-\mathrm{VB} 4 \mathrm{r}$ & $\mathrm{SERS}$ & $0.67-26.67 \mathrm{ng} / \mathrm{mL} \mathrm{RHCG}$ & $\Delta I_{1615 \mathrm{~cm}-1}=47.5 \mathrm{C}+2.3$ & 0.9969 \\
& $\mathrm{RRS}$ & $3.33-26.67 \mathrm{ng} / \mathrm{mL} \mathrm{RHCG}$ & $\Delta I_{370 \mathrm{~nm}}=30.3 \mathrm{C}+36.4$ & 0.9794 \\
& $\mathrm{UV}$ & $0.67-26.67 \mathrm{ng} / \mathrm{mL} \mathrm{RHCG}$ & $\Delta A_{570 \mathrm{~nm}}=0.11 \mathrm{C}+0.0338$ & 0.9675
\end{tabular}

catalysis, respectively. The RRS peak at $300 \mathrm{~nm}$ was chosen for detection of HCG, with high sensitivity.

SPR Absorption Spectra. The SPR absorption spectral technique is a simple and low-cost tool to examine some nanoparticles such as AuNPs in solution and was chosen for the AuNP reaction. For the $\mathrm{GO}-\mathrm{HAuCl}_{4}-\mathrm{H}_{2} \mathrm{O}_{2}$ nanoreaction (Figure 4a), the product of AuNPs exhibited a SPR absorption peak at about $580 \mathrm{~nm}$, and the peak appeared to blue-shift with increasing GO concentration that indicated the formed AuNP size decreased. For the AuNP- $\mathrm{HAuCl}_{4}-\mathrm{H}_{2} \mathrm{O}_{2}$ system (Figure $4 \mathrm{~b}$ ), the product of AuNPs exhibited a SPR absorption peak at about $520 \mathrm{~nm}$, and these results indicated that the formed small AuNPs in the reaction procces could also catalyze the nanoparticle reaction; that is, there is self-catalysis in the system. The spectra of the RHCG-GO-HAuCl $4-\mathrm{H}_{2} \mathrm{O}_{2}$ and RHCG-HCG-GO-HAuCl${ }_{4}-\mathrm{H}_{2} \mathrm{O}_{2}$ systems (Figure 4c) showed that the catalytic activity of the GO nanoenzyme inhibited by RHCG and HCG recovery the GO activity, and the absorption value at $530 \mathrm{~nm}$ could be used for detection of HCG selectively (Figure 4d).

GO Catalysis and Its Mechanism. The three spectral techniques including SERS, RRS, and SPR absorption were 


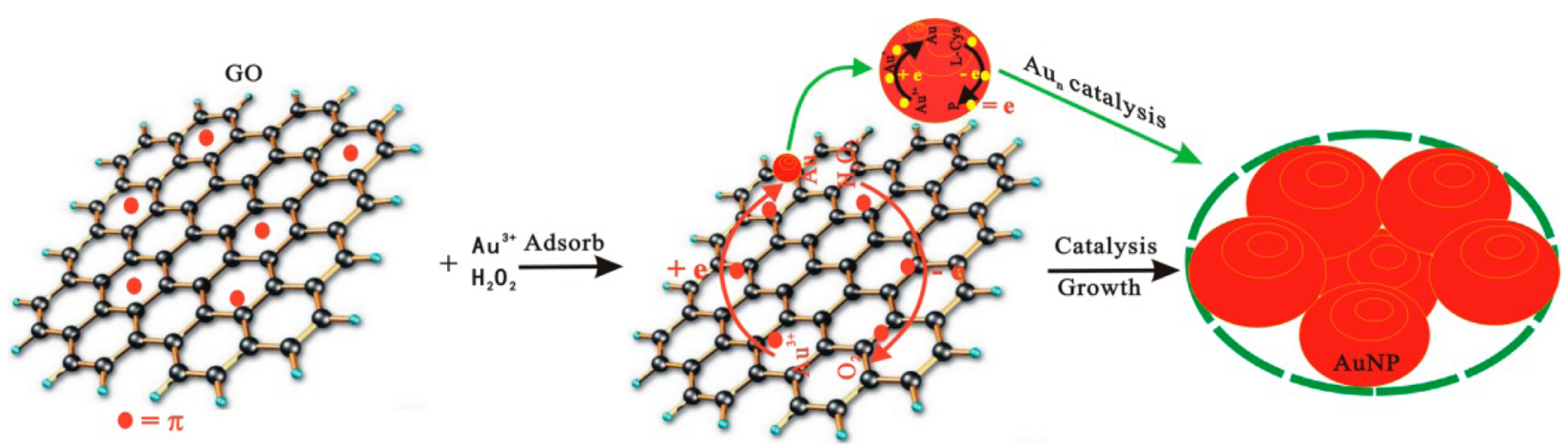

Nanosurface $\pi$ electrons enhance

the redox electron-transfer

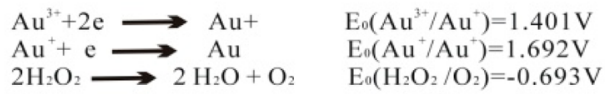

Figure 5. GO catalytic mechanism for the $\mathrm{H}_{2} \mathrm{O}_{2}$ reduction of $\mathrm{HAuCl}_{4}$ to form AuNPs. The GO surface had abundant surface $\pi$ electrons that enhanced the redox electron transfer of $\mathrm{H}_{2} \mathrm{O}_{2}-\mathrm{HAuCl}_{4}$ to form small AuNPs rapidly and growth. Meanwhile, the small AuNPs also catalyzed the redox reaction to form more AuNPs, that is, autonanocatalysis.

used to study the AuNP reaction of $\mathrm{HAuCl}_{4}-\mathrm{H}_{2} \mathrm{O}_{2}$. Results (Table 1) showed that the SERS and RRS intensity and SPR absorption value increased linearly with the GO catalyst concentration increasing, and the SERS is most sensitive with biggest slope in the linear equation. The AuNPs with size of 8 $\mathrm{nm}$ also exhibited catalysis of the AuNP reaction, but it is less than the activity of GO. However, when RHCG concentration increased, the SERS and RRS intensity and SPR absorption value decreased linearly. The reason was that they could be attached to the surface of the GO nanocatalyst by intermolecular forces, to block the contact between the catalyst and the reactants and inhibit the catalytic activity.

The heterogeneous electron transfer of $\mathrm{sp}^{2}$ carbons occurs at the edges and defects and not at the basal plan of graphene sheets. ${ }^{33}$ Oxygen-containing groups on the GO surface and the super high surface area provided by its two-dimensional structure can enhance the electron transfer rate. ${ }^{54,55}$ In the experimental conditions, the redox nanoparticle reaction of $\mathrm{HAuCl}_{4}-\mathrm{H}_{2} \mathrm{O}_{2}$ could be catalyzed by GO and small AuNPs but does not speed by graphene that does not dissolve in water, and the GO catalysis is stronger than the AuNPs in size of $8 \mathrm{~nm}$. We speculate that the smaller AuNPs formed in the reaction process have stronger catalysis. For the nanocatalytic system, when the VB4r was used as the SERS probe, the SERS peak at $I_{1617 \mathrm{~cm}-1}$ was the most obvious change, and the SERS effect increased linearly related to the nanocatalyst concentration. Accordingly, The RRS intensity/SPR absorption and the nanocatalyst concentration also had a linear relationship. In short, $\mathrm{H}_{2} \mathrm{O}_{2}$ and $\mathrm{HAuCl}_{4}$ could adsorb to the GO surface that is of hydrophilic and hydrophobic domains and has abundant surface $\pi$ electrons, and the redox electron transfer could be enhanced greatly by means of the $\pi$ electrons; meanwhile, the formed small AuNPs in the redox process could catalyze the redox to form more AuNPs (Figure 5).

TEM and ED. The transmission electron microscopy (TEM) is used to observe the particle size and surface morphology. The TEM (Figure 6) of the RHCG-HCG-GO$\mathrm{H}_{2} \mathrm{O}_{2}-\mathrm{HAuCl}_{4}$ system was recorded, and it showed that the gold nanoparticles in solution were less in the absence of HCG, with an average size of $25 \mathrm{~nm}$. When HCG was added into the solution, the generated gold nanoparticles with size of $15 \mathrm{~nm}$ increased due to the nanocatalyst GO concentration increasing, and all three energy spectral peaks are at 1.7, 2.1, and 9.7 keV for the Au element.

Optimization of Analysis Conditions. For the RHCG$\mathrm{HCG}-\mathrm{GO}-\mathrm{H}_{2} \mathrm{O}_{2}-\mathrm{HAuCl}_{4}-\mathrm{VB} 4 \mathrm{r}$ system, the analytical conditions, including GO, RHCG, $\mathrm{HCl}, \mathrm{HAuCl}_{4}, \mathrm{H}_{2} \mathrm{O}_{2}$, and VB4r, the reaction temperature, and time (Figure $\mathrm{S} 2$ ) were optimized, respectively. The effects of GO concentration on the $\Delta I_{1616 \mathrm{~cm}-1}$ were investigated, and a $50 \mathrm{ng} / \mathrm{mL} \mathrm{GO}$ was selected to use. The effects of RHCG concentration on $\Delta I_{1616 \mathrm{~cm}-1}$ were investigated, and when it reached $13.33 \mathrm{ng} / \mathrm{mL}$, the value of $\Delta I_{1616 \mathrm{~cm}-1}$ was the largest; therefore, $13.33 \mathrm{ng} / \mathrm{mL}$ was selected. The dosage of $\mathrm{HCl}$ was optimized, and when the concentration of $\mathrm{HCl}$ was $0.15 \mathrm{mmoL} / \mathrm{L}, \Delta I_{1616 \mathrm{~cm}-1}$ reached the maximum value. A value of $0.15 \mathrm{mmoL} / \mathrm{L} \mathrm{HCl}$ was chosen. When the $\mathrm{HAuCl}_{4}$ concentration was $6.3 \mu \mathrm{moL} / \mathrm{L}$, the $\Delta I_{1616 \mathrm{~cm}-1}$ value was the largest and was selected for use. When the $\mathrm{H}_{2} \mathrm{O}_{2}$ concentration was $2.5 \mathrm{mmoL} / \mathrm{L}$, the value of $\Delta I_{1616 \mathrm{~cm}-1}$ was the largest, and $2.5 \mathrm{mmoL} / \mathrm{L} \mathrm{H}_{2} \mathrm{O}_{2}$ was chosen. The VB4r probe concentration was considered, and the value of $\Delta I_{1616 \mathrm{~cm}-1}$ was the largest when the concentration of $\mathrm{VB} 4 \mathrm{r}$ achieved $0.375 \mu \mathrm{moL} / \mathrm{L}$; therefore, $0.375 \mu \mathrm{moL} / \mathrm{L}$ VB4r was selected. Under the optimal reagent conditions, the reaction temperature and time were examined. A reaction time of $8 \mathrm{~min}$ at $50{ }^{\circ} \mathrm{C}$, giving the largest $\Delta I_{1616 \mathrm{~cm}-1}$, was selected for use. GO also catalyzed the gold nanoparticle reaction of $\mathrm{TCA}-\mathrm{HAuCl}_{4}$, and the RHCGHCG-GO-TCA-HAuCl $-\mathrm{HB} 4 \mathrm{r}$ system could be used for SERS detection of HCG. The conditions of the RHCGHCG-GO-TCA-HAuCl $4-\mathrm{VB} 4 \mathrm{r}$ system were optimized (Figure S3). A $13.33 \mathrm{ng} / \mathrm{mL}$ RHCG, $50 \mathrm{ng} / \mathrm{mL}$ GO, 0.34 $\mathrm{mmoL} / \mathrm{L}$ TCA, $5.6 \mu \mathrm{moL} / \mathrm{L} \mathrm{HAuCl}_{4}, 0.167 \mathrm{mmoL} / \mathrm{L} \mathrm{HCl}$, and $0.25 \mu \mathrm{moL} / \mathrm{L} \mathrm{VB} 4 \mathrm{r}$ and a reaction temperature of $60^{\circ} \mathrm{C}$ for 10 min were selected for use. The analytical conditions of the RHCG-HCG-GO-GS-HAuCl $-\mathrm{VB} 4 \mathrm{r}$ system were examined (Figure S4). A $0.5 \mathrm{mmoL} / \mathrm{L} \mathrm{HCl}, 100 \mathrm{ng} / \mathrm{mL} \mathrm{GO}, 20 \mathrm{ng} /$ $\mathrm{mL}$ RHCG, $50 \mathrm{mmoL} / \mathrm{L} \mathrm{GS}, 5.6 \mu \mathrm{moL} / \mathrm{L} \mathrm{HAuCl}_{4}$, and 0.33 $\mu \mathrm{moL} / \mathrm{L} \mathrm{VB} 4 \mathrm{r}$ and a reaction temperature of $75^{\circ} \mathrm{C}$ for $20 \mathrm{~min}$ were selected for use.

Working Curve. For the system of RHCG-HCG-GO$\mathrm{H}_{2} \mathrm{O}_{2}-\mathrm{HAuCl}_{4}-\mathrm{VB} 4 \mathrm{r}$, the SERS effect was enhanced with increasing HCG concentration, and the SERS intensity 

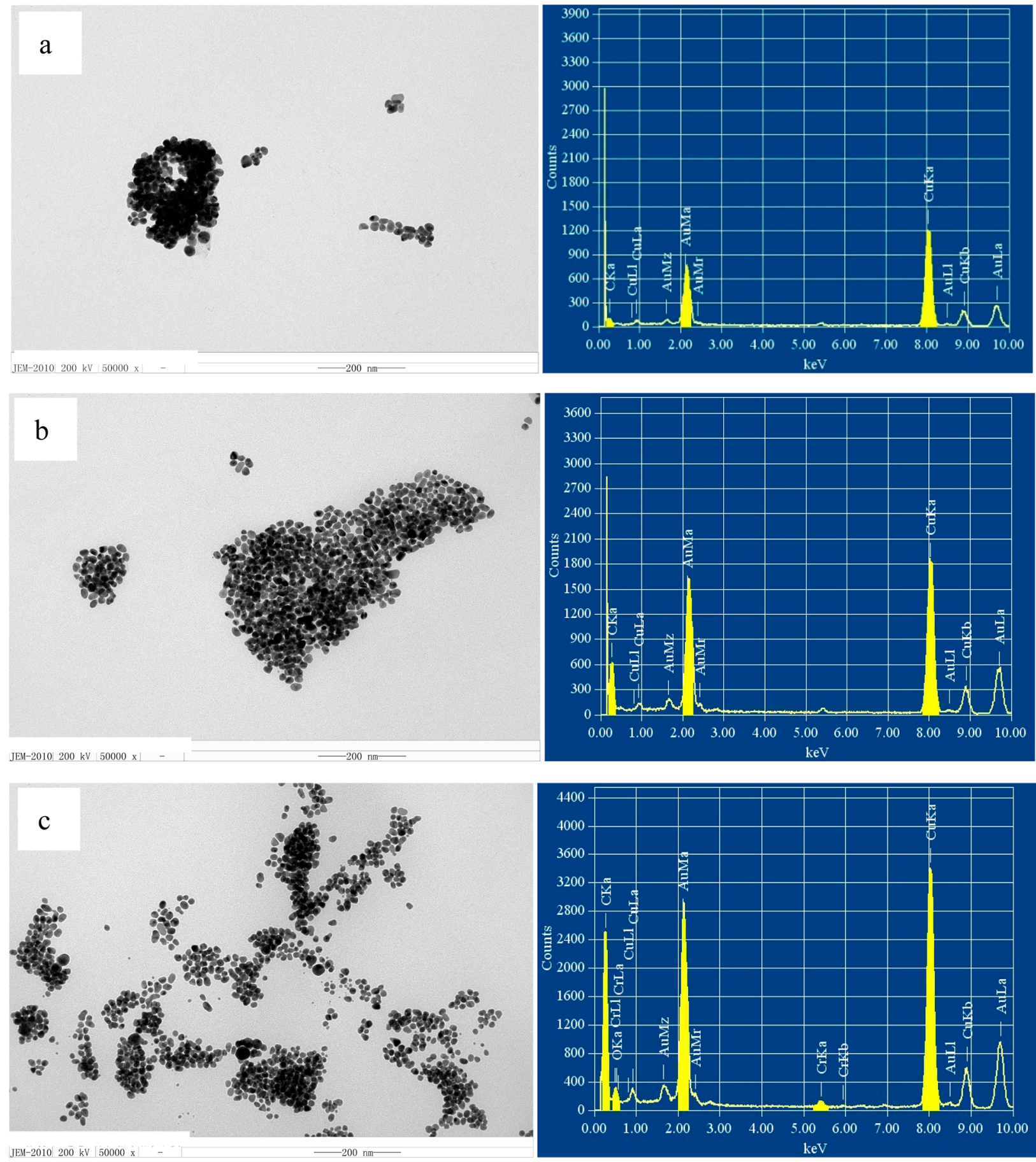

Figure 6. TEM and ED of the nanocatalytic analysis sysytem. (a) $35 \mathrm{nmoL} / \mathrm{L} \mathrm{RHCG}+50 \mathrm{ng} / \mathrm{mL} \mathrm{GO}+0.15 \mathrm{mmoL} / \mathrm{L} \mathrm{HCl}+2.5 \mathrm{mmoL} / \mathrm{L} \mathrm{H} \mathrm{O}_{2}+$ $6.3 \mu \mathrm{moL} / \mathrm{L} \mathrm{HAuCl}_{4}$. (b) a $+2.5 \mathrm{ng} / \mathrm{mL}$ HCG. (c) a $+10 \mathrm{ng} / \mathrm{mL} \mathrm{HCG}$.

Table 2. Comparison of the Immunocontrolling GO Catalytic Reaction: Spectral Methods for HCG

\begin{tabular}{llclcc}
\multicolumn{1}{c}{ system } & methods & detection range $\mathrm{ng} / \mathrm{mL}$ & \multicolumn{1}{c}{ regress equation } & coefficient & LOD $\mathrm{ng} / \mathrm{mL}$ \\
$\mathrm{H}_{2} \mathrm{O}_{2}-\mathrm{HAuCl}_{4}$ & SERS & $0.2-13.3$ & $\Delta I_{1617 \mathrm{~cm}-1}=101.6 \mathrm{C}+31.8$ & 0.9905 & 0.07 \\
$\mathrm{H}_{2} \mathrm{O}_{2}-\mathrm{HAuCl}_{4}$ & $\mathrm{RRS}$ & $0.5-18$ & $\Delta I=83.7 \mathrm{C}+108$ & 0.9847 & 0.20 \\
$\mathrm{H}_{2} \mathrm{O}_{2}-\mathrm{HAuCl}_{4}$ & Abs & $1.0-18$ & $\Delta A=0.0308 \mathrm{C}+0.036$ & 0.9619 & 0.50 \\
$\mathrm{TCA}_{\mathrm{HAuCl}}$ & SERS & $0.67-20.0$ & $\Delta I_{1615 \mathrm{~cm}-1}=43.1 \mathrm{C}-50.8$ & 0.9972 & 0.22 \\
$\mathrm{GS}-\mathrm{HAuCl}_{4}$ & SERS & $0.67-26.67$ & $\Delta I_{1618 \mathrm{~cm}-1}=55.2 \mathrm{C}+36.4$ & 0.995 & 0.25 \\
\hline
\end{tabular}

$\Delta I_{1617 \mathrm{~cm}-1}$ had a good linear relationship with $\mathrm{HCG}$ concentration in the range of $0.25-10 \mathrm{ng} / \mathrm{mL}$, with a linear equation of $\Delta I_{1617 \mathrm{~cm}-1}=101.6 \mathrm{C}+31.8$, a correlation coefficient of 0.9905 , and a detection limit of $0.07 \mathrm{ng} / \mathrm{mL}$, and the RRS and $\mathrm{Abs}$ working curves were also obtained. For the system of $\mathrm{RHCG}-\mathrm{HCG}-\mathrm{GO}-\mathrm{TCA}-\mathrm{HAuCl}_{4}-\mathrm{VB} 4 \mathrm{r}$, the linear range is 
0.67-20 ng/mL HCG, with a linear equation of $\Delta I_{1615 \mathrm{~cm}-1}=$ 143.1C - 50.8, a coefficient of 0.9972 , and a detection of 0.5 $\mathrm{ng} / \mathrm{mL}$. For the system of RHCG-HCG-GO-GS-HAuCl ${ }_{4}-$ VB4r, the linear range is $0.67-26.67 \mathrm{ng} / \mathrm{mL} \mathrm{HCG}$, with a linear equation of $\Delta I_{1618 \mathrm{~cm}-1}=55.2+36.4$, a coefficient of 0.995 , and a detection limit of $0.25 \mathrm{ng} / \mathrm{mL}$. From Table 2, we can see that the SERS system of $\mathrm{HAuCl}_{4}-\mathrm{H}_{2} \mathrm{O}_{2}$ is the most sensitive, which was chosen for sample detection. Although the sensitivity of the absorption method is inferior to the SERS and RRS methods, the cost is lowest. The sensitivity and cost of the RRS method are between the SERS and RRS methods.

Interference. The effect of the coexisting substances on the system for the SERS detection of $10 \mathrm{ng} / \mathrm{mL}$ HCG was investigated. The tested common interfering ions and amino acids, IgG and IgM, did not interfere with the determination when the relative error was within $10 \%$ (Table S2). It indicated that this nanocatalytic SERS method had good electivity

Analysis of Samples. Five serum samples of women were offered by the No.5 People's Hospital of Guilin, Guangxi, China, and a $1.0 \mathrm{~mL}$ sample was diluted to $100 \mathrm{~mL}$ with water before determination. The following operations were according to the procedure of the $\mathrm{RHCG}-\mathrm{HCG}-\mathrm{GO}-\mathrm{H}_{2} \mathrm{O}_{2}-\mathrm{HAuCl}_{4}-$ VB4r system. In addition, recovery tests were performed. The results (Table S3) show that the recoveries were in the range of 96.40-98.76\%, and the RSDs were in the range of $0.93-3.97 \%$. The obtained results were not obviously different from clinical diagnosis values of the No.5 People's Hospital, so the results demonstrate that the method was accurate and reliable.

\section{CONCLUSIONS}

First, the $\mathrm{GO}-\mathrm{H}_{2} \mathrm{O}_{2}-\mathrm{HAuCl}_{4}$ nanocatalytic particle reaction was studied in detail by SERS, RRS, and SPR absorption techniques. Then, the antibody protein adsorbed on the surface of GO nanoparticles, which blocked the binding of the nanoenzyme to the reactants and inhibited its catalytic action, and the enhancement of catalytic effect led to the increase of SERS effect when the antigen was added. Finally, according to this principle of immunecontrolling GO activity, a new SERS method for HCG was established. Furthermore, other immunoreactions would combine with the GO catalysis to develop the SERS detection platform.

\section{EXPERIMENTAL SECTION}

Apparatus. A model of DXR smart Raman spectrometer (Thermo Company, United States) with laser wavelength of $633 \mathrm{~nm}$ and power of $3.0 \mathrm{~mW}$, a model of Cary Eclipse fluorescence spectrophotometer (Varian Company, United States), and a model of TU-1901 double-beam UV-visible spectrophotometer (Beijing General Instrument Co., LTD, China) were used.

Reagents. A $0.50 \mathrm{mg}$ human chorionic gonadotropin (HCG, Beijing Boosen Biotechnology Co., Ltd.) freeze-dried powder was dissolved in $1.0 \mathrm{~mL}$ of water and then diluted to 10 $\mathrm{mL}$ to obtain a $50 \mu \mathrm{g} / \mathrm{mL}$ HCG standard solution. The solution was diluted to a solution of $1 \mu \mathrm{g} / \mathrm{mL}$ before use. A 0.1 $\mathrm{mg} / \mathrm{mL}$ rabbit antibody of HCG (RHCG, Beijing Boosen Biotechnology Co., Ltd.), $84 \mu \mathrm{moL} / \mathrm{L}(1 \%) \mathrm{HAuCl}_{4} \cdot 4 \mathrm{H}_{2} \mathrm{O}$ (Sinopharm Chemical Reagent Co., Ltd.), $0.1 \mathrm{moL} / \mathrm{L}_{2} \mathrm{O}_{2}$, $1 \%$ trisodium citrate (TCA, Guangdong Shantou Xilong Chemical Factory), $0.5 \mathrm{moL} / \mathrm{L}$ glucose (GS), $0.1 \mathrm{moL} / \mathrm{L}$ $\mathrm{HCl}, 0.3 \mathrm{~mol} / \mathrm{L} \mathrm{CH}_{3} \mathrm{COOH}$, and $0.1 \mathrm{mmoL} / \mathrm{L}$ Victoria blue 4R (VB4r) were prepared. Graphene oxide (GO) was prepared by the Hummer procedure, ${ }^{30}$ and $1 \mathrm{mg}$ of GO was dissolved in $100 \mathrm{~mL}$ of water by means of ultrasound to obtain a concentration of $10 \mu \mathrm{g} / \mathrm{mL}$ of GO. AuNPs with size of $8 \mathrm{~nm}$ were prepared by the $\mathrm{NaBH}_{4}$ procedure. All reagents are analytically pure, and the water was double-distilled.

Procedure. We put a moderate amount of GO, RHCG, and HCG into a $5 \mathrm{~mL}$ test tube and mixed well. Then, $\mathrm{H}_{2} \mathrm{O}_{2}, \mathrm{HCl}$, and $\mathrm{HAuCl}_{4}$ were added into the test tube, diluted to $1.5 \mathrm{~mL}$ and mixed well, reacted in a water bath for a certain time, and cooled with tap water. Finally, molecular probes of VB4r were added, diluted to $2 \mathrm{~mL}$, and mixed well. The mixture was transferred into a quartz cell, and we recorded its SERS spectra. The SERS peak intensity $I_{1615 \mathrm{~cm}-1}$ and the blank $\left(I_{1615 \mathrm{~cm}-1}\right)_{0}$ without HCG were recorded, and the $\Delta I_{1615 \mathrm{~cm}-1}=I_{1615 \mathrm{~cm}-1}-$ $\left(I_{1615 \mathrm{~cm}-1}\right)_{0}$ was calculated.

\section{ASSOCIATED CONTENT}

\section{Supporting Information}

The Supporting Information is available free of charge on the ACS Publications website at DOI: 10.1021/acsomega.7b01335.

SERS spectra, curves of optimization condition, Table of assignment of SERS peaks, influence of the coexisting substances and analytical results (PDF)

\section{AUTHOR INFORMATION}

\section{Corresponding Authors}

*Guiqing Wen. E-mail: gqwen@mailbox.gxnu.edu.cn.

*Zhiliang Jiang. E-mail: zljiang@gxnu.edu.cn.

ORCID

Zhiliang Jiang: 0000-0002-6252-7081

\section{Author Contributions}

X.L.W., C.N.L., and A.H.L. contributed equally to this work.

Notes

The authors declare no competing financial interest.

\section{ACKNOWLEDGMENTS}

This work is supported by the National Natural Science Foundation of China (No.21767004, 21667006, 21465006, 21477025), the University Key Laboratory of Karst Ecology and Environmental Change of Guangxi Province (No. YRHJ16Z009), the doctor scientific research foundation of Hezhou University (HZUBS201608), and the professor scientific research foundation of Hezhou University (HZUJS201613).

\section{REFERENCES}

(1) Gao, L. Z.; Zhuang, J.; Nie, L.; Zhang, J. B.; Zhang, Y.; Gu, N.; Wang, T. H.; Feng, J.; Yang, D. L.; Perrett, S. Intrinsic peroxidase-like activity of ferromagnetic nanoparticles. Nat. Nanotechnol. 2007, 2, 577-583.

(2) Kim, Y. S.; Jurng, J. A simple colorimetric assay for the detection of metal ions based on the peroxidase-like activity of magnetic nanoparticles. Sens. Actuators, B 2013, 176, 253-257.

(3) Lien, C. W.; Huang, C. C.; Chang, H. T. Peroxidase-mimic bismuth-gold nanoparticles for determining the activity of thrombin and drug screening. Chem. Commun. 2012, 48, 7952-7954.

(4) Jiang, X.; Sun, C. J.; Guo, Y.; Nie, G. J.; Xu, L. Peroxidase-like activity of apoferritin paired gold clusters for glucose detection. Biosens. Bioelectron. 2015, 64, 165-170.

(5) Gao, Z. Q.; Hou, L.; Xu, M. D.; Tang, D. P. Enhanced Colorimetric Immunoassay Accompanying with Enzyme Cascade Amplification Strategy for Ultrasensitive Detection of Low-Abundance Protein. Sci. Rep. 2015, 4, 3966. 
(6) Zhuang, J.; Lai, W.; Chen, G.; Tang, D. Rolling circle amplification-based DNA machine for miRNA screening coupling catalytic hairpin assembly with DNAzyme formation. Chem. Commun. 2014, 50, 2935-2938.

(7) Zhuang, J.; Lai, W.; Xu, M.; Zhou, Q.; Dianping, T. Plasmonic AuNP/g- $\mathrm{C}_{3} \mathrm{~N}_{4}$ Nanohybrid-based Photoelectrochemical Sensing Platform for Ultrasensitive Monitoring of Polynucleotide Kinase Activity Accompanying DNAzyme-Catalyzed Precipitation Amplification. ACS Appl. Mater. Interfaces 2015, 7, 8330-8338.

(8) Hou, L.; Tang, Y.; Xu, M.; Gao, Z.; Tang, D. P. Tyramine-Based Enzymatic Conjugate Repeats for Ultrasensitive Immunoassay Accompanying Tyramine Signal Amplification with Enzymatic Biocatalytic Precipitation. Anal. Chem. 2014, 86, 8352-8358.

(9) Lantman, E. M. S.; Deckert-Gaudig, T.; Mank, A. J. G.; Deckert, V.; Weckhuysen, B. M. Catalytic processes monitored at the nanoscale with tip-enhanced Raman spectroscopy. Nat. Nanotechnol. 2012, 7, $583-586$.

(10) Zhang, Q. Q.; Li, X. S.; Ma, Q.; Zhang, Q.; Bai, H.; Yi, W. C.; Liu, J. Y.; Han, J.; Xi, G. C. A metallic molybdenum dioxide with high stability for surface enhanced Raman spectroscopy. Nat. Commun. 2017, 8, 14903.

(11) Lin, K. Q.; Yi, J.; Zhong, J. H.; Hu, S.; Liu, B. J.; Liu, J. Y.; Zong, C.; Lei, Z. C.; Wang, X.; Aizpurua, J.; Esteban, R.; Ren, B. Plasmonic photoluminescence for recovering native chemical information from surface-enhanced Raman scattering. Nat. Commun. 2017, 8, 1489114895 .

(12) Shamaila, S.; Khan, A.; Sajjad, L.; Ryma, N. A.; Farooqi, S. A.; Jabeen, N.; Majeed, S.; Farooq, I. Advancements in nanoparticle fabrication by hazard free eco-friendly green routes. Appl. Mater. Today 2016, 5, 150-199.

(13) Li, M. X.; Yang, H.; Li, S. Q.; Zhao, K.; Li, J. G.; Jiang, D. N.; Sun, L. L.; Deng, A. P. Ultrasensitive and quantitative detection of a new $\beta$-agonist phenylethanolamine A by a novel immunochromatographic assay based on surface-enhanced Raman scattering (SERS). J. Agric. Food Chem. 2014, 62, 10896-10902.

(14) Fan, M. K.; Cheng, F.; Wang, C.; Gong, Z.; Tang, C.; Man, C.; Brolo, A. G. SERS Optrode as a "fishing rod" to direct pre-concentrate analytes from superhydrophobic surfaces. Chem. Commun. 2015, 51, 1965-1968.

(15) Kho, K. W.; Dinish, U. S.; Kumar, A.; Olivo, M. Frequency shifts in SERS for biosensing. ACS Nano 2012, 6, 4892-4902.

(16) Sun, D. H.; Zhang, G. L.; Jiang, X. D.; Huang, J. L.; Jing, X. L.; Zheng, Y. M.; He, J.; Li, Q. B. Biogenic flower-shaped Au-Pd nanoparticles: synthesis, SERS detection and catalysis towards benzyl alcohol oxidation. J. Mater. Chem. A 2014, 2, 1767-1773.

(17) Yang, G.; Ma, Y.; Xu, J. Biomimetic catalytic system driven by electron transfer for selective oxygenation of hydrocarbon. J. Am. Chem. Soc. 2004, 126, 10542-10543.

(18) Chen, D. J.; Wang, Y. T.; Klankermayer, J. Enantioselective hydrogenation with chiral frustrated Lewis pairs. Angew. Chem., Int. Ed. 2010, 49, 9475-9478.

(19) Su, D. S.; Zhang, J.; Frank, B.; Thomas, A.; Wang, X. C.; Paraknowitsch, J.; Schlögl, R. Metal-free heterogeneous catalysis for sustainable chemistry. ChemSusChem 2010, 3, 169-180.

(20) Figueiredo, J. L.; Pereira, M. F. R. The role of surface chemistry in catalysis with carbons. Catal. Today 2010, 150, 2-7.

(21) Song, Y. J.; Qu, K. G.; Zhao, C.; Ren, J. S.; Qu, X. G. Graphene oxide: Intrinsic peroxidase catalytic activity and its application to glucose detection. Adv. Mater. 2010, 22, 2206-2210.

(22) Qian, J.; Yang, X. W.; Yang, Z. T.; Zhu, G. B.; Mao, H. P.; Wang, $\mathrm{K}$. Multiwalled carbon nanotube reduced graphene oxide nanoribbon heterostructure: synthesis, intrinsic peroxidase-like catalytic activity, and its application in colorimetric biosensing. J. Mater. Chem. B 2015, 3, 1624-1632.

(23) Joshi, R. K.; Alwarappan, S.; Yoshimura, M.; Sahajwalla, V.; Nishina, Y. Graphene oxide: the new membrane materialReview Article. Appl. Mater. Today 2015, 1, 1-12.
(24) Chua, C. K.; Pumera, M. . Chemical reduction of graphene oxide: a synthetic chemistry viewpoint. Chem. Soc. Rev. 2014, 43, 291312.

(25) Giovanni, M.; Poh, H. L.; Ambrosi, A.; Zhao, G.; Sofer, Z.; Šaněk, F.; Khezri, B.; Webster, R. D.; Pumera, M. Noble metal (Pd, $\mathrm{Ru}, \mathrm{Rh}, \mathrm{Pt}, \mathrm{Au}, \mathrm{Ag}$ ) doped graphene hybrids for electrocatalysis. Nanoscale 2012, 4, 5002-5008.

(26) Loo, A. H.; Bonanni, A.; Ambrosi, A.; Poh, H. L.; Pumera, M. Impedimetric immunoglobulin $\mathrm{G}$ immunosensor based on chemically modified graphenes. Nanoscale 2012, 4, 921-925.

(27) He, X. D.; Wei, Z. J.; Liu, Y. X.; Ren, Q. L. The preparation of graphene oxide and using it as catalyst for the hydrolyzation of soybean isoflavone. J. Chem. Eng. Chin. Univ. 2012, 26, 56-60.

(28) Gao, X. Q.; Zhu, S. H.; Li, Y. W. Graphene oxide as a facile solid acid catalyst for the production of bioadditives from glycerol esterification. Catal. Commun. 2015, 62, 48-51.

(29) Dhopte, K. B.; Raut, D. S.; Patwardhan, A. V.; Nemade, P. R. Graphene oxide as recyclable catalyst for one-pot synthesis of $\alpha$ aminophosphonate. Synth. Commun. 2015, 45, 778-788.

(30) Wang, S. M.; Xu, L. L.; Wang, L. S.; Liang, A. H.; Jiang, Z. L. A new and simple resonance Rayleigh scattering method for human serum albumin using graphene oxide as probe. Luminescence 2013, 28, 842-846.

(31) Hao, R.; Zhang, C. J.; Lu, Y.; Zhang, D. J.; Hao, Y. W.; Liu, Y. Q. Preparation and surface-enhanced Raman scattering effect of graphene oxide/ (Au/Ag) hybrid materials. Progr. Chem. 2016, 28, 1186-1195.

(32) Banchelli, M.; Tiribilli, B.; Angelis, M.; Pini, R.; Caminati, G.; Matteini, P. Controlled veiling of silver nanocubes with graphene oxide for improved surface-enhanced Raman scattering detection. ACS Appl. Mater. Interfaces 2016, 8, 2628-2634.

(33) Wang, S.; Cazelles, R.; Liao, W. C.; Vázquez-González, M.; Zoabi, A.; Abu-Reziq, R.; Willner, I. Mimicking horseradish peroxidase and $\mathrm{NADH}$ peroxidase by heterogeneous $\mathrm{Cu}^{2+}$-modified graphene oxide nanoparticles. Nano Lett. 2017, 17, 2043-2048.

(34) Fan, S.; Zhao, M.; Ding, L.; Li, H.; Chen, S. Preparation of $\mathrm{Co}_{3} \mathrm{O}_{4} /$ crumpled graphene microsphere as peroxidase mimetic for colorimetric assay of ascorbic acid. Biosens. Bioelectron. 2017, 89, 846852.

(35) Liu, F.; Tang, J.; Xu, J.; Shu, Y.; Xu, Q.; Wang, H.; Hu, X. Low potential detection of indole-3-acetic acid based on the peroxidase-like activity of hemin/reduced graphene oxide nanocomposite. Biosens. Bioelectron. 2016, 86, 871-8.

(36) Xue, Z.; Yin, B.; Wang, H.; Li, M.; Rao, H.; Liu, X.; Zhou, X.; $\mathrm{Lu}, \mathrm{X}$. functionalized graphene oxide nanocomposite-based colorimetric assay for the detection of sarcosine. Nanoscale 2016, 8, 548896.

(37) Li, Z.; Xu, S. C.; Zhang, C.; Liu, X. Y.; Gao, S. S.; Hu, L. T.; Guo, J.; Ma, Y.; Jiang, S. Z.; Si, H. P. High-performance SERS substrate based on hybrid structure of graphene oxide/AgNPs/Cu film@pyramid Si. Sci. Rep. 2016, 6, 38539.

(38) Lee, J.; Kim, J.; Kim, S.; Min, D. H. Biosensors based on graphene oxide and its biomedical application. Adv. Drug Delivery Rev. 2016, 105, 275-287.

(39) Evans, J. Hyperglycosylated HCG: a unique human implantation and invasion factor. Am. J. Reprod. Immunol. 2016, 75, $333-340$.

(40) Lee, I. H.; Lee, J. M.; Jung, Y. Controlled protein embedment onto $\mathrm{Au} / \mathrm{Ag}$ core-shell nanoparticles for immuno-labeling of nanosilver surface. ACS Appl. Mater. Interfaces 2014, 6, 7659-64.

(41) Kamińska, A.; Witkowska, E.; Winkler, K.; Dzięcielewski, I.; Weyher, J. L.; Waluk, J. Detection of hepatitis B virus antigen from human blood: SERS immunoassay in a microfluidic system. Biosens. Bioelectron. 2015, 66, 461-7.

(42) Ashaduzzaman, M.; Deshpande, S. R.; Murugan, N. A.; Mishra, Y. K.; Turner, A. P.; Tiwari, A. On/off-switchable LSPR nanoimmunoassay for troponin-T. Sci. Rep. 2017, 7, 44027.

(43) Cui, C.; Chen, Y.; Jiang, D.; Zhu, J. J.; Chen, H. Y. Attomole Antigen Detection Using Self-Electrochemiluminous Graphene Oxide- 
Capped Au@L012 Nanocomposite. Anal. Chem. 2017, 89, 24182423.

(44) Roushani, M.; Valipour, A. Using electrochemical oxidation of Rutin in modeling a novel and sensitive immunosensor based on $\mathrm{Pt}$ nanoparticle and graphene-ionic liquid-chitosan nanocomposite to detect human chorionic gonadotropin. Sens. Actuators, B 2016, 222, $1103-1111$.

(45) Yang, L.; Zhao, H.; Fan, S. M.; Deng, S. S.; Lv, Q.; Lin, J.; Li, C. $\mathrm{P}$. Label-free electrochemical immunosensor based on gold-silicon carbide nanocomposites for sensitive detection of human chorionic gonadotrophin. Biosens. Bioelectron. 2014, 57, 199-206.

(46) Park, J. M.; Jung, H. W.; Chang, Y. W.; Kim, H. S.; Kang, M. J.; Pyuna, J. C. Chemiluminescence lateral flow immunoassay based on $\mathrm{Pt}$ nanoparticle with peroxidase activity. Anal. Chim. Acta 2015, 853, $360-367$.

(47) Tian, Z. Q.; Ren, B.; Wu, D. Y. Surface-enhanced Raman scattering: From noble to transition metals and from rough surfaces to ordered nanostructure. J. Phys. Chem. B 2002, 106, 9463-9483.

(48) Deb, S. K.; Davis, B.; Knudsen, G. M.; Gudihal, R.; Ben-Amotz, D.; Davisson, V. J. J. J. Am. Chem. Soc. 2008, 130, 9624-9625.

(49) Chen, Y.; Chen, Z. P.; Long, S. Y.; Yu, R. Q. Generalized ratiometric indicator based surface-enhanced Raman spectroscopy for the detection of $\mathrm{Cd}^{2+}$ in environmental water samples. Anal. Chem. 2014, 86, 12236-12242.

(50) Wen, G. Q.; Liang, X. J.; Liu, Q. Y.; Liang, A. H.; Jiang, Z. L. A novel nanocatalytic SERS detection of trace human chorionic gonadotropin using labeled-free Vitoria blue $4 \mathrm{R}$ as molecular probe. Biosens. Bioelectron. 2016, 85, 450-456.

(51) Liu, Y.; Huang, C. Z. Screening sensitive nanosensors via the investigation of shape-dependent localized surface plasmon resonance of single Ag nanoparticles. Nanoscale 2013, 5, 7458-7466.

(52) Ren, W.; Zhang, Y.; Chen, H. G.; Gao, Z. F.; Li, N. B.; Luo, H. Q. Ultrasensitive label-free resonance Rayleigh scattering aptasensor for $\mathrm{Hg}^{2+}$ using $\mathrm{Hg}^{2+}$-triggered exonuclease III-assisted target recycling and growth of G-wires for signal amplification. Anal. Chem. 2016, 88, $1385-1390$.

(53) Davies, T. J.; Hyde, M. E.; Compton, R. G. Nanotrench arrays reveal insight into graphite electrochemistry. Angew. Chem., Int. Ed. 2005, 44, 5121-5126.

(54) Liu, Y.; Liu, Y.; Feng, H.; Wu, Y.; Joshi, L.; Zeng, X.; Li, J. Layerby layer assembly of chemical reduced graphene and carbon nanotubes for sensitive electrochemical immunoassay. Biosens. Bioelectron. 2012, $35,63-68$.

(55) Tang, L.; Wang, Y.; Li, J. The graphene/nucleic acid nanobiointerface. Chem. Soc. Rev. 2015, 44, 6954-6980. 